\title{
The Chinese vs. Western Media Framing on Uygur Conflict
}

\section{Aucky Adi Kurniawan}

Departement of International Relations, University of Muhammadiyah Malang.Email:auckykurniawan021@webmail.umm.ac.id

\section{Al Dina Maulidya}

Departement of International Relations, University of Muhammadiyah Malang. Email:aldinamaulidyaa@webmail.umm.ac.id

\section{Khaerul Sa'ban}

Departement of International Relations, University of Muhammadiyah Malang.Email:young99786@webmail.umm.ac.id

\section{Indrawati}

Departement of International Relations, University of Muhammadiyah Malang.Email: indrakwati@webmail.umm.ac.id

\begin{abstract}
This paper focuses on the Uyghur conflict, which became international news. Many reports about the Uygur appear with religious-based heroic narratives that corroborate discrimination, persecution, and the Chinese government's mistake against the Uyghur ethnic minority. It aims to understand the difference in Western mass media's preaching compared to the Chinese mass media informing Uyghur-related news. Compared to other ethnicity issues, the authors believed in specific interests behind the preaching of various online mass media to what was happening in Xinjiang. The authors used the explanative method with the framework of the framing theory of Pan Konciski and the constructivist paradigm to interpret the news of the Uygur conflict. The study results show Western media are more likely to use words or sentences that drain the reader's emotions, while Chinese media are more likely to be neutral in framing the news. It is a record for the authors that the public perception regarding the internationalization of issues occurring in a country can be influenced by how the media package news content.
\end{abstract}


Keywords: Mass Media of western, Mass Media of China, Uyghur, Political Instruments.

\section{Abstrak}

Artikel ini berfokus pada konflik Uyghur yang menjadi berita internasional. Banyak laporan tentang Uygur muncul dengan narasi heroik berbasis agama yang menguatkan diskriminasi, penganiayaan, dan kesalahan pemerintah China terhadap etnis minoritas Uyghur. Ini bertujuan untuk memahami perbedaan pemberitaan media massa Barat dibandingkan dengan media massa Tiongkok yang menginformasikan berita terkait Uyghur. Dibandingkan masalah etnis lainnya, penulis meyakini adanya kepentingan spesifik di balik pemberitaan berbagai media massa online hingga apa yang terjadi di Xinjiang. Penulis menggunakan metode eksplanatif dengan kerangka teori framing Pan Konciski dan paradigma konstruktivis untuk menafsirkan berita konflik Uygur. Hasil studi menunjukkan media Barat lebih cenderung menggunakan kata-kata atau kalimat yang menguras emosi pembacanya, sedangkan media China lebih cenderung netral dalam membingkai pemberitaan. Ini menjadi catatan bagi penulis bahwa persepsi publik mengenai internasionalisasi isu yang terjadi di suatu negara dapat dipengaruhi oleh bagaimana media mengemas konten berita.

Kata Kunci: Media Massa Barat, Media Massa Tiongkok, Uyghur, Instrumen Politik.

\section{INTRODUCTION}

Xinjiang is the westernmost region in China. This region is directly adjacent to Turkey in Central Asia, East Turkestan. The Uyghurs, who have initially been East Turkestan residents, originally came from the Proto-Turkish ethnic group who inhabited Central Asia to the Turkish republic's territory. Therefore, there must be a closeness bond built between the countries in Central Asia, Turkey and the Uyghurs (Laylia, 2010). In the beginning, Xinjiang named East Turkestan before they merged with China. In the 17th century, East Turkestan was colonized by the Chinese, ruled by the Qing Dynasty. However, East Turkestan succeeded in taking over its country again until 1949. The Soviet Union 
saw the triumph of this Muslimdominated region so that it was seen as a threat. In the same year, a split arose between nationalist supporters and the CCP in China. The Soviet Union then gave full support toward Mao Zedong to take over East Turkestan, and eventually, East Turkestan officially changed into Xinjiang. The collapse of the Soviet Union in 1991 brought independence to the countries in Central Asia, namely Kazakhstan, Uzbekistan, Turkmenistan and Kirgizstan. However, it is tragic for the Uyghurs, not the independence they get but the increasing pressure from the Chinese government (Laylia, 2010).

In 1950, the Chinese government implemented a domestic migration policy. This policy brought about eight million Han Chinese to move and live there (Ding, 2018). The Chinese government gave superiority to ethnic Han by supporting them to have higher positions in the government. After the death of Mao Zedong, many demonstrations were carried out by students and residents. The biggest riots between the Uyghurs and Han people occurred on July 5, 2009 (Laylia, 2010). According to human rights groups, the riots perpetrated by the Uyghurs could not be separated from restrictions or acts of discrimination against the religious, cultural and racialethnic Uyghur minority (Ferdian \& Utomo, 2018). Certain elements then used this riot to divide China and show the existence of separatist movements in Xinjiang involving the Uyghur Islamic community (Ferdian \& Utomo, 2018). Another accusation through the White Book from the state council Information Office stated that this minority in Xinjiang had been used as an instrument to support the interests of pro-Turkish and pro-Islam groups (BBC, 2018). This particular group's interests made China feel the need to maintain the country's unity.

In this case of imbalanced development between Han ethnic and Uyghurs, Uyghurs are even more disadvantaged in welfare. China's government also had a restrictive religion policy (Wei \& Cuifen, 2012). The Chinese government then tried to imply some policies to balance the economic development in Xinjiang. However, China leaders were also concerned with this concept because they assumed that people with a better economy and education were more likely to strengthen their ethnic identity, threatening national integrity. So, the Chinese government also 
implied some policies regarding nationalism. Those policies are related to nationalism and are already stated in China's White Paper. They had the policy to own vocational and educational training of Uyghurs in Xinjiang (US-China Institute, n.d.). In the Xinjiang Work Forum, there was an "Ethnic Mingling" policy (Jamestown, n.d.). With those policies, China's government provided them both political re-education and economic development.

Most people might be unfamiliar with "the vocational and educational training" for Uyghur in Xinjiang. The policy that the Chinese government already stated could also be called with "Strike Hard against Violent Terrorist Activity" campaign. Strike Hard campaigns began as anti-crime operations to assure the public of the state's ability to provide security (Byman \& Saber, 2019). These camps have been compared to internment camps. The Uyghurs have to recite Chinese laws and Communist Party policies, learning Mandarin, singing songs about the CCP and Xi Jinping, and renouncing religious beliefs in those camps (Blanchard, n.d.). Due to these policies, the Chinese government got much criticism for violating human rights. Based on global perception about the ethnic conflict of Uyghur are discriminate issues for their freedom of having religion, tradition, culture and language as well.

Meanwhile, in China's govern_ ment perception, they eliminated ethnic problems and extinguished extremism and fought terrorism to solve Xinjiang's problems and protect Xinjiang as their territory. Xinjiang province is known as one of the wealthy regions in China. Based on data, Xinjiang's GDP growth is significant than in any other region in China because Xinjiang has both the beauty of nature and culture that attracts tourism. Hence, Xinjiang's existence is also crucial for the Chinese Government's Belt Road Initiative (Chinadaily.com.cn).

Phenomena that occur in a country, such as an act of rebellion or applying a policy, will always be preached to the international world. The news was disseminated through various media, such as newspapers, magazines, journal publications, articles, etc. According to Mc Quail, quoted by Aria Aditya Setiawan, the mass media is one way to develop culture (Aria Sditya Setiawan, 2013)discourse is just one term that scholars have developed to analyze the systems of thoughts, ideas, images and other symbolic 
practices that make up what we, following anthropology, generally call culture. Other terms have their limitations though: 1 . This culture is defined as art, symbols, fashion, lifestyle and norms. The development of information and communication technology now makes the distribution of information/news flows more freely. According to Ashadi Siregar in Husnul Khatimah's quote, online media can be interpreted as a general designation for a form of media based on telecommunications and multimedia (computers and the internet) (Khatimah, 2018). Online media consist of news portals, websites, online radio, online television viewing, online press releases, etc. Online media can facilitate the public to enjoy information or news and entertainment through the internet.

If viewed from the content, a journalist's story is usually inclined towards certain parties (Rahmayuni, 2020). The Chinese mass media called Guo Ji Ri Bao published news related to China's defense amidst Uyghur ethnic discrimination (Rahmayuni, 2020). The media said that the news related to the persecution activities experienced by the Uyghurs had been exaggerated. The camps were a center for honesty training and many other festive activities.

Meanwhile, news from the BBC, a mass media from the West, provided information if Beijing discriminated against ethnic minorities in the Uyghur. They were detained in camps suspected of being a place of reeducation in Xinjiang. It was also a place to suppress the formation of developing Islamic extremists in China (BBC, 2018). Western mass media also believed that the Chinese government's involvement with several community organizations from other countries came to the camps.

The difference in reporting is due to the interests carried by each country of origin of the mass media. There was a significant ideological difference between the United States of liberal ideology and Soviet Communism (Eka Afriyansyah, 2015). China is a country that is still carrying out the ideology of socialist-communism (Lubis, 2017). Thus, there will be differences between Western media and Chinese media in presenting news related to Uyghur. The Chinese mass media will defend their country, so they try to present news that benefits their country's position. Meanwhile, Western media from 
the United States, such as the BBC, ABC News, New York Times, and others, will preach everything they say as "truth" without taking China's side. Therefore, in this study, the Chinese mass media and Western mass media will see their role in constructing people by becoming a political weapon.

In the current era of globalization, mass media is no longer a means of entertainment media, but it can be one of the weapons owned by a country in shaping the public image of a country or that we can now know as a proxy war. Mass media not only brings out the constructed reality, or the mass media is not only good at creating frames from a news story. However, the media has also acted as an instrument of propaganda and foreign political instruments that are a surefire and bridge to war. With its role as a media propaganda, the mass media can grab fast public support (international community support). The formula on the research reads: "How Western mass media and China's mass media can be a political instrument thought the issue of Uyghur?". This article is to know the different perspectives of Western and China mass media about how they frame the news and understand how mass media can be a political instrument.

\section{The Paradigm of Constructivism}

The paradigm of this study is the paradigm of constructivism. This paradigm has its position or view of the media, and the news text it generates. The concentration of analysis on this paradigm to discover how events or reality was constructed, in what way it was constructed was formed. Peter L. Berger first introduced the concept of constructionism. According to Berger, the reality is not formed scientifically; instead, it is formed and constructed. Everyone has different constructions of reality. This paradigm looks at a reality exposure in the news text due to "the maker" construction, so the reality of the show's events is not a natural event (Eriyanto, 2008, pp. 13-15). In this case, how the western mass media and the mass media of China manage to construct society and the international community.

The term social construction of reality became very popular since its introduction by Peter L. Berger and Thomas Luckmann. Social reality is a life-like knowledge that lives and develops in the community, such as concepts, public awareness, and public discourse, resulting 
from social construction (Bungin, 2006, pp. 191-192). Media is a construction agency of reality. Media content is the result of workers who construct the reality it chooses. The news describes reality and shows the opinion of news sources, also the media's construction. According to Peter L Berger, the theory believes that reality has a subjective and objective dimension. That reality is the result of human thought. As social individuals, people have never stagnated as long as they live in their society. Technically, Berger and Luckmann's central thesis is human, and society is the product that is dialectical, dynamic, and plural continuously.

According to Berger and Luckmann (Eriyanto, 2008, pp. 1419), the dialectical process has three phases: externalization, objectivity, and internalization. These theories and approaches look at variables over mass media phenomena into substance in the externalization, objectivity, and internalization processes through social mass media construction. Thus, nature or excess mass media has improved the social construction process's weakness that runs slow reality. The substance "mass media construction theory" is on rapid and widespread circulation so that social construction takes place quickly, and the spread is evenly (Bungin, 2006, p. 207).

These theories and approaches look at variables over mass media phenomena into substance in the externalization, objectivity, and internalization processes through social mass media construction. Thus, nature or excess mass media has improved the social construction process's weakness that runs slow reality. The substance "mass media construction theory" is on rapid and widespread circulation so that social construction takes place quickly, and the spread is evenly (Bungin, 2006, p. 207). With the foundation of thought theory of social reality construction that explains how reality is formed, it will help understand how events or how the phenomenon develops into reality. The preaching conducted by the Western mass media and the Chinese mass Media on the Strike Hard policy conducted by the Chinese government against the Uyghur ethnic is not separated from the news of the case's construction. The reality of the Chinese government enforcing the Strike rigid policy is formed when journalists or media see the fact, then how the media is applying it, and how the media constructs the facts to be revealed to be news. 
The method used in this research was the method of framing analysis. Framing has been used in the communication research literature to examine how the selection and construction process the reality of a medium performed by a medium. Besides, this Pan and Kosicki model can be conducted through discourse devices such as words, sentences, leads or images, or tools to understand the media in packaging the news. (Eriyanto, 2008, pp. 257-266)

\section{RESULT AND EXPLANATION}

\section{A. Mass Media of China}

1. News: Allegedly 'Missing' Uyghurs Found Living Normally - Global Times

\begin{tabular}{|c|c|l|}
\hline No. & Indicator & Result of Research \\
\hline 1. & What & $\begin{array}{l}\text { The 'missing' } \\
\text { Uyghurs that were } \\
\text { viral in global } \\
\text { media were found } \\
\text { by the Global } \\
\text { Times (Chinese } \\
\text { Media) staff to } \\
\text { have an everyday } \\
\text { life in Xinjiang, } \\
\text { and they were } \\
\text { getting disturbed } \\
\text { and confused by } \\
\text { the spreading } \\
\text { false rumor of the } \\
\text { western media. }\end{array}$ \\
\hline
\end{tabular}

\begin{tabular}{|c|c|l|}
\hline No. & Indicator & Result of Research \\
\hline 2. & When & December 2019 \\
\hline 3. & Where & Xinjiang, China \\
\hline 4. & Who & $\begin{array}{l}\text { The Uyghur family } \\
\text { and also the family } \\
\text { member was } \\
\text { suspected of joining } \\
\text { the separatist group, } \\
\text { East Turkistan. }\end{array}$ \\
\hline $\mathbf{5 .}$ & Why & $\begin{array}{l}\text { There were found } \\
\text { tweets on social } \\
\text { media, saying that } \\
\text { many Uyghurs had } \\
\text { been missing. }\end{array}$ \\
\hline $\mathbf{6 .}$ & How & $\begin{array}{l}\text { Staff from Global } \\
\text { Times found the } \\
\text { missing Uyghurs } \\
\text { after investigating } \\
\text { tweets on social } \\
\text { media. }\end{array}$ \\
\hline
\end{tabular}

Description of the news:

In December 2019, the suspected Uyghurs joining the East Turkistan, Ruzi Memet, claimed that his brother was missing and post that statement on Twitter with the hashtag \#StillNoInfo and talked about that his family had been suffering from the concentration camp in Xinjiang. The tweet was posted right after China's government announced the graduation from vocational education and training centers of trainee once influenced by extreme thoughts in Xinjiang. 
After that tweet popped up, then there was another tweet saying no missing people in Uyghur. Global times staff investigated the case to reveal the truth. After discovering the online information from some organizations and some individuals on the alleged missing Uyghurs, the authorities in Xinjiang confirm and visiting some of the "lost people" in different places in Xinjiang, but the Global Times (GT) reporters found the fact that they are living everyday lives.

This news told how the 'missing' Uyghurs were doing fine in Xinjiang and having everyday life. Revealing their daily routines life, and also there was a short documentary video of the Uyghurs. The interview with the Uyghurs showed that Uyghurs in Xinjiang did not have any discrimination. Instead, they were grateful for having vocational education training. They said that it prevented them from extremism and made their life more valued. The news also stated that knowing those false spreading false rumors were disturbing (Jie \& Juecheng.). This news from media under the Chinese government denied what western media talked about violence in concentration camps and proof of a Uygur's daily life in Xinjiang and even constructed the mindset that vocational and educational training effectively prevented extremism in Xinjiang.

2. News: Rumors of 'Forced Labor' in Xinjiang Refuted - Global Times

\begin{tabular}{|c|c|c|}
\hline \multicolumn{2}{|c|}{ No. Indicator } & Result of Research \\
\hline 1. & What & $\begin{array}{l}\text { Lawmakers and } \\
\text { Australian think } \\
\text { tank organization } \\
\text { have been sparing } \\
\text { no effort on hyping } \\
\text { up the "forced labor } \\
\text { conspiracy" in } \\
\text { Northwest China's } \\
\text { Xinjiang Uygur } \\
\text { Autonomous Region } \\
\text { and also pursuing a } \\
\text { bill to limit Xinjiang } \\
\text { export activities to } \\
\text { the US }\end{array}$ \\
\hline 2. & When & December 2019 \\
\hline 3. & Where & Xinjiang, China \\
\hline 4. & Who & $\begin{array}{l}\text { Workers in Xinjiang, } \\
\text { Companies that } \\
\text { implicated in "forced } \\
\text { labor" reports by the } \\
\text { western media }\end{array}$ \\
\hline 5. & Why & $\begin{array}{l}\text { A report showing } \\
\text { that there was forced } \\
\text { labor in Xinjiang }\end{array}$ \\
\hline
\end{tabular}




\begin{tabular}{|c|c|l|}
\hline No. & Indicator & Result of Research \\
\hline 6. & How & $\begin{array}{l}\text { The staff of the } \\
\text { Global Times } \\
\text { investigated the case } \\
\text { by visiting more } \\
\text { than } 70 \text { companies } \\
\text { in Xinjiang }\end{array}$ \\
\hline
\end{tabular}

Description of the news:

US politicians have been trying to push China's sanctions over socalled forced labor in Xinjiang to have possible restrictions in future strategic confrontations. This effort is also accompanied by a report from the US and Australia, stating that forced labor inside and outside of Xinjiang's vocational education and training centers is "systematic repression" of minority groups. From the two reports, many US lawmakers and politicians were pursuing a bill in the last week to implement stringent limits on imports from Xinjiang, knowing that The Global Times staffs decided to visit more than 70 companies and private workshops in four prefectures in southern Xinjiang and found that accusations of forced labor in China were false. The "dirty campaign" launched by antiChina groups would undermine the livelihoods of the Uygurs and other people located in Xinjiang who lived in poverty. The Global Times reached all of the companies and stated that there was no forced labor happening in their factories, and the jobs could help financial issues of the Uyghur workers and their families. The Global Times also stated that the World Uyghur Congress, a US-backed regime, worsened the mediass situation. Both government and companies denied all of the report's false statements and embraced how they helped Uyghurs survive from poverty.

In this news, Chinese media and the people in Xinjiang admitted that the local government had already provided services for transferring labor, and residents voluntarily signed up for them. The local government mentioned that everything wa under control. “The 'dirty campaign' from the US politicians and media outlets had already undermined, and the result would undermine the livelihood of Uygurs and other residents in Xinjiang who were currently living," said the workers in Xinjiang. By having the statement, the media stressed that every company in Xinjiang did not have any behavior (forced labor) toward the Uyghurs ethnic (Global Times Staff.). This news from the media under the Chinese government once again shaped how Xinjiang was excellent, and the Chinese government did 
not have any mistreatment behavior toward Uyghurs in Xinjiang. The media could also frame the US in this case and desperately want China to fall by having a statement about World Uyghur Congress and the US's irrational attitude for targeting the companies. Meanwhile, there were also companies from the US in Xinjiang.

\section{B. Mass Media of Western}

1. News: Inside China's Push to Turn Muslim Minorities into an Army of Workers - The New York Times

\begin{tabular}{|c|c|c|}
\hline No. & Indicator & Result of Research \\
\hline 1. & What & $\begin{array}{l}\text { Forcing Uyghurs } \\
\text { to take part in } \\
\text { learning activi- } \\
\text { ties in working in } \\
\text { training camps, if } \\
\text { they refused, the } \\
\text { Chinese gov- } \\
\text { ernment would } \\
\text { threaten their } \\
\text { families }\end{array}$ \\
\hline 2. & When & December 30, 2019 \\
\hline 3. & Where & $\begin{array}{l}\text { Uyghurs and } \\
\text { Kazakhs }\end{array}$ \\
\hline 4. & Who & $\begin{array}{l}\text { The Government } \\
\text { of China, Uyghurs } \\
\text { and Kazakhs }\end{array}$ \\
\hline
\end{tabular}

\begin{tabular}{|c|c|l|}
\hline No. & Indicator & Result of Research \\
\hline 5. & Why & $\begin{array}{l}\text { This minority } \\
\text { made up about } \\
\text { half of the popu- } \\
\text { lation and were } \\
\text { considered neces- } \\
\text { sary for the gov- } \\
\text { ernment's social } \\
\text { reengineering } \\
\text { strategy in indoc- } \\
\text { trination camps, } \\
\text { accommodating } \\
\text { one million or } \\
\text { more Uighurs and } \\
\text { Kazakhs to estab- } \\
\text { lish control over } \\
\text { the Uyghur and } \\
\text { Kazakh regions }\end{array}$ \\
\hline 6. & $\begin{array}{l}\text { To control the Uy- } \\
\text { ghur Territory and } \\
\text { the Kazakhs, the } \\
\text { Chinese govern- } \\
\text { ment implemented } \\
\text { training camps. } \\
\text { The Qapqal labor } \\
\text { bureau ordered } \\
\text { that villagers un- } \\
\text { derwent military- } \\
\text { style training to } \\
\text { convert them into } \\
\text { obedient work- } \\
\text { ers, loyal to their } \\
\text { employers and the } \\
\text { ruling Communist } \\
\text { Party. }\end{array}$ \\
\hline
\end{tabular}


Description of the news:

This media reported about the Chinese government forcing Uighurs and Kazakhs to do vocational training and be separated from their families (Chris Buckley, 2020). In training, the Chinese government used a military-style that suppressed Uyghurs and Kazakhs to be loyal to the ruling communist party. The Chinese government stated that Uyghur and Kazakh villages were "rural surplus labor" and unemployed populations that threatened social stability. Placing them in governmentapproved work is overseen, officials would eradicate poverty and slow the spread of religious extremism and ethnic violence.

The Chinese government described workers as volunteers, although critics said that they were forced. Official documents, interviews with experts, and The New York Times's visit to Xinjiang showed that local plans to deprive villagers limited their movements and pressured them to keep working. There are also reports that workers were not paid according to their work. For example, Amanzhol Qisa, a 31-year-old Xinjiang resident, spent a year in an indoctrination camp, and she was sent to do a labor job in a clothing factory for three months in April. She was paid \$ 115 a month, less than half the minimum wage, according to her husband, Muhamet Qyzyrbek. To be released, workers must accept all policies of the Chinese government.

2. News: 'Absolutely No Mercy': Leaked Files Expose How China Organized Mass Detentions of Muslims - The New York Times

\begin{tabular}{|c|c|c|}
\hline No. & Indicator & Result of Research \\
\hline 1. & What & $\begin{array}{l}\text { - The leaking of } \\
\text { the file revealed } \\
\text { how China or- } \\
\text { ganized mass ar- } \\
\text { rests of Muslims. } \\
\text { - More than } 400 \\
\text { pages of China's } \\
\text { internal docu- } \\
\text { ments provided } \\
\text { a view into } \\
\text { something that } \\
\text { never happened } \\
\text { before about } \\
\text { a crackdown } \\
\text { against ethnic } \\
\text { minorities in the } \\
\text { Xinjiang region. }\end{array}$ \\
\hline 2. & When & August 2016 \\
\hline 3. & Where & Xinjiang, China \\
\hline 4. & Who & $\begin{array}{l}\text { Xi Jinping's } \\
\text { President, Chen } \\
\text { Quanguo }\end{array}$ \\
\hline
\end{tabular}




\begin{tabular}{|l|c|l|}
\hline No. Indicator & Result of Research \\
\hline 5. & $\begin{array}{l}\text { There is evidence of } \\
\text { violence committed } \\
\text { by President Xi } \\
\text { Jinping, party } \\
\text { leader, against } \\
\text { the Uyghur Tribe } \\
\text { because it was } \\
\text { based on the } \\
\text { stabbing carried out } \\
\text { by terrorists. }\end{array}$ \\
\hline How & $\begin{array}{l}\text { The most signifi- } \\
\text { cant leak of govern- } \\
\text { ment papers from } \\
\text { within the ruling } \\
\text { Chinese Com- } \\
\text { munist Party in } \\
\text { decades; They were } \\
\text { provided an inward } \\
\text { view of the ongo- } \\
\text { ing persecution in } \\
\text { Xinjiang, where } \\
\text { authorities dragged } \\
\text { as many million } \\
\text { ethnic Uyghurs, } \\
\text { Kazakhs and oth- } \\
\text { ers into detention } \\
\text { camps and prisons } \\
\text { over the past three } \\
\text { years. } \\
\text { Senior party leaders } \\
\text { were noted to have } \\
\text { ordered drastic } \\
\text { and urgent action } \\
\text { against extremist } \\
\text { violence, including } \\
\text { mass detention. }\end{array}$ \\
\hline
\end{tabular}

\begin{tabular}{|l|l|}
\hline No. Indicator & Result of Research \\
\hline & $\begin{array}{l}\text { The leaked papers } \\
\text { consisted of } 24 \\
\text { documents, some } \\
\text { of which contained } \\
\text { duplicated mate- } \\
\text { rial. That included } \\
\text { nearly } 200 \text { pages of } \\
\text { internal speech by } \\
\text { Mr. Xi and other } \\
\text { leaders, and more } \\
\text { than } 150 \text { landing } \\
\text { pages and reports } \\
\text { on the supervision } \\
\text { and control of the } \\
\text { Uighur population } \\
\text { in Xinjiang. There } \\
\text { are also references } \\
\text { to plans to expand } \\
\text { Islamic restrictions } \\
\text { to other parts of } \\
\text { China. }\end{array}$ \\
\hline
\end{tabular}

\section{Description of the news:}

The New York Times reported that there had been leaked secret files that explained the Chinese behavior towards the Uyghurs. It would prove the Chinese government's lies who said the camp, as a job training center that used lightweight methods to combat Islamic extremism (Austin Ramzy, 2020). However, the documents confirmed the nature of the imposition of measures loud in words and commands of the officers who compose and arrange. 
The New York Times illustrated that the leaking files' contents were the party seniors who recorded ordered actions drastic and urgent against violent extremists, including the detention of mass and discussed the consequences with detachment cold. In the media, China's government wanted to rule Xinjiang's region with sources of power by limiting the activities of the Muslims Uyghur's culture and religion. Their detention by the authorities in Xinjiang was against hundreds of thousands of Uyghurs, Kazakhs, and Muslims in the camps internment camp. The prisoners underwent many months or years of indoctrination and interrogation, which aimed to transform them into supporters of the party that was secular and loyal.

In his speech, the media proclaimed that $\mathrm{Xi}$ Jinping said that Islam in Uyghur was religious extremists, so the assumption was led to the attack on Uyghur, and $\mathrm{Xi}$ argued that extremism Islam had its roots in swaths of society in Uyghur. Most great Uyghurs embraced the tradition of moderate, although some began to embrace the practices of religion that were more conservative and more common in the 1990s, although there was control of the state against Islam. This media believed that Xi Jinping's lies were caused by worrying about the rise of public piety. He blamed that the controls were weak in faith because the predecessor lowered guard them.

\section{Mass Media of Western and Mass Media of China Becom- ing an Instrument of Political Interest}

With globalization and integration happening, they have made a new world order. State actors and non-states and other actors such as INGO, NGO, MNC, Business actor, and Private Sector have added a treasure in the international world. Today, the media play an essential role in forming public opinion in China. Mass media not only brings out the constructed reality, or the mass media is not only good at creating frames from a news story. The media has also acted as an instrument of propaganda and foreign political instruments with a surefire and bridge to war. With its role as a media propaganda, the mass media can grab fast public support (international community support).

In its announcement of the Uyghur Muslim conflict, the Global Times tends to bring out the frame to uphold humanitarian principles with a political approach. From the two 
titles, Global Times displays clearly by not compromising the concern of Uyghur Muslim conditions. It is reinforced by the expression of the Global Times' sentence so that it posed an impression on the public that what was done by the Chinese government was humanist and caring about humanity. The Global Times emphasized humanist aspects with a political approach through titles, news schemes, and sources. From news headlines, the Global Times put the Muslim Uyghur as a party to be aware of its parallels and salvation. The title of the news was accompanied by a political theme by the pro-Uighur speakers.

The New York Times in spreading the Uyghur Muslim conflict has not been more than a frame that has to build the public opinion that the Chinese governments were responsible and liable for Muslim Uyghur's tribulations. Through both its news headlines, the New York Times features a public image of the Chinese government with the editorial of a sentence that the Chinese government describes as the wrong party to implement a reeducation of the Uyghur Muslim community accompanying violence and persecution. The New York Times also impressed the heavy side in displaying portions of the news, as more of a portion of condemnation to the Chinese government than the further explanation of the Chinese government itself was related to the re-education to Muslim Uyghur. The New York Times also features the Muslim Uyghur as the Dehumanization object of the Chinese government.

\section{CONCLUSION}

China and America are two big countries with different histories and ideological backgrounds. As a national mass media from China with political alignments of the Chinese Communist Party, the Global Times continues to provide news that tends to his country's government. On the other hand, the national mass media from America, the New York Times, always presents news that increasingly highlights the "reality" of how China is doing various ways for its interests. So, the two mass media became instruments of political interest by framing many reports about the Uyghur issue.

\section{REFERENCES}

Aria Sditya Setiawan. (2013). Peran Media Massa Dalam Meningkatkan Kualitas Kepemerintahan Lokal Berbasis Human Security Di Kota Jayapura. 2(2), 39- 
48. https://doi.org/10.14710/ politika.2.2.2011.39-48

Austin Ramzy, C. B. (2020). 'Absolutely No Mercy': Leaked Files Expose How China Organized Mass Detentions of Muslims. Retrieved April 6, 2020, from nytimes.com website: https://www.nytimes. com/interactive/2019/11/16/ world/asia/china-xinjiangdocuments.html

BBC. (2018). Cina bantah menahan satu juta warga minoritas Muslim Uighur - BBC News Indonesia. Retrieved October 6, 2019, from BBC Indonesia website: https://www.bbc.com/ indonesia/dunia-45177355

Bennett, W. L. (2004). GLOBAL MEDIA AND POLITICS: Transnational Communication Regimes and Civic Cultures. Annual Review of Political Science, 7(1), 125-148. https:// doi.org/10.1146/annurev. polisci.7.012003.104804

Blanchard, B. (n.d.). China says pace of Xinjiang "education" will slow but defends camps.

Bungin, B. (2006). Sosiologi Komunikasi: Teori, Paradigma, dan Diskursus Teknologi Komunikasi di Masyarakat. In Kencana Jakarta. Jakarta.
Byman, D. L., \& Saber, I. (2019). Is China prepared for global terrorism? Xinjiang and beyond. (September), 1-16.

Chinadaily.com.cn. (n.d.). Xinjiang at the heart of Belt, Road Opinion -.

Chris Buckley, A. R. (2020). Inside China's Push to Turn Muslim Minorities Into an Army of Workers - The New York Times. Retrieved April 17, 2020, from nytimes.com website: https:// www.nytimes.com/2019/12/30/ world/asia/china-xinjiangmuslims-labor.html

Culpepper, R. (2012). Nationalist competition on the internet: Uyghur diaspora versus the Chinese state media. Asian Ethnicity, 13(2), 187-203. https://doi.org/10.1080/146313 69.2012.625711

Ding, M. (2018). Security matters in marriage: Uyghurs' perceptions of security in Xinjiang, China. Central Asian Survey, 37(1), 85-99. https://doi.org/10.1080 /02634937.2017.1338247

Eka Afriyansyah. (2015). ANALISA DEMOKRASI LIBERAL FRANCIS FUKUYAMA, Menggunakan teori Libertarian menurut Robert Nozick. 1-19. Retrieved from http://lib.ui.ac. 
id/naskahringkas/2017-04/ S58205-Eka Afriyansyah

Eriyanto. (2008). Analisis Framing: Konstruksi, Ideologi, dan Politik Media. In LKiS Yogyakarta. Yogyakarta.

Ferdian, H., \& Utomo, S. (2018). Nasib Muslim Uighur di China, antara Isu Pelanggaran HAM dan Separatisme. Retrieved from https://www.liputan6.com/ news/read/3839349/headlinenasib-muslim-uighur-di-chinaantara-isu-pelanggaran-hamdan-separatisme

Global Times Staff. (n.d.). Rumors of "forced labor" in Xinjiang refuted.

Hidayat, M. N. (2013). Diaspora Uyghur dan Hak Sipil di Xinjiang Cina. Interdependence Jurnal, 1(3), 165-179. Retrieved from https://pdfs. semanticscholar.org/cc7f/26fb eb10a870f075b7e51592b01609 8affd4.pdf

Jamestown. (n.d.). Xinjiang Work Forum Marks New Policy of 'Ethnic Mingling.'

Jie, S. and, \& Juecheng, Z. (n.d.). Allegedly 'missing' Uyghurs found living normally.

Karisma, G. (2017). Konflik Etnis di Xinjiang: Kebijakan Monokultural dan Kepentingan
Negara China Terhadap Keutuhan Wilayah. In Jurnal Sosiologi (Vol. 19). Retrieved from http://repository.lppm. unila.ac.id/6158/1/364-712-1PB.pdf

Karnanta, S. W. dan K. Y. (2019). Perbandingan Representasi Etnis Uighur di Media Berita China Daily dan BBC. 8(1), 36-51. Retrieved from https:// e-journal.unair.ac.id/LAKON/ article/view/9330

Khatimah, H. (2018). Posisi Dan Peran Media Dalam Kehidupan Masyarakat. Tasamuh, 16(1), 119-138. https:// doi.org/10.20414/tasamuh. v16il.548

Laylia, S.N.(2010). RESPONTURKI TERHADAP PELANGGARAN HAM MINORITAS MUSLIM UIGHUR YANG DILAKUKAN OLEH PEMERINTAH TIONGKOK 2009-2010. JOM UNRI, 5(1), 1-11. Retrieved from https://jom.unri.ac.id/ index.php/JOMFSIP/article/ download/17474/16878

Lubis, F. H. (2017). Sosialisme Pasar China. Politika, Vol. 8, pp. 64-75. Retrieved from https://ejournal.undip.ac.id/ index.php/politika/article/ download/17627/12560 
Muslich, M. (2008). Kekuasaan Media Massa Mengonstruksi Realitas. Jurnal Budaya Dan Seni, 2(36), 150-158. Retrieved from http://sastra.um.ac.id/ wp-content/uploads/2009/10/ Kekuasaan-Media-MassaMengontruksi-RealitasMasnur-Muslich.pdf

Poti, J. (2011). Demokratisasi Media Massa dalam Prinsip Kebebasan. Ilmu Politik Dan Ilmu Pemerintahan, 1(1), 17-29. Retrieved from http:// fisip.umrah.ac.id/wp-content/ uploads/2012/03/JURNALILMU-PEMERINTAHAN BARU-KOREKSI-last.23-35.pdf Rahmayuni, D. (2020). Hierarki Pengaruh Isu-Isu Moderasi Beragama pada Media Guo Ji Ri Bao 国 际日报 Studi Kasus Berita Konflik Etnis Uighur di Xinjiang. 1(2), 1-24. Retrieved from http://journal.uinjkt. ac.id/index.php/jsj/article/ viewFile/14568/6953

Uber Silalahi. (2009). Metode Penelitian Sosial. Bandung: Refika Adhitama.
US-China Institute. (n.d.). PRC State Council White Paper, China's Ethnic Policy and Common Prosperity and Development of All Ethnic Groups.

Wei, S., \& Cuifen, W. (2012). China's "new deal" in xinjiang and its challenges. In China: Development and Governance (pp. 71-80). https://doi. org/10.1142/97898144258 58_0009

Zenz, A. (2019). 'Thoroughly reforming them towards a healthy heart attitude': China's political re-education campaign in Xinjiang. Central Asian Survey, 38(1), 102-128. Retrieved from https:/www.tandfonline.com/ doi/pdf/10.1080/02634937.201 8.1507997?needAccess=true

Zhu, D. (2017). Hero and Villain on a Foreign Land: A Textual Analysis on US Newspaper Coverage of China's Uighur Unrest. SHS Web of Conferences, 33, 00017. https://doi. org/10.1051/shsconf/2017330 0017 